Прегледни чланак/ Review Paper

ЗНАЧАЈ ФАРМАКОГЕНЕТИКЕ

У ТЕРАПИЈСКОЈ ПРИМЕНИ КЛОПИДОГРЕЛА

\author{
Немања Ранчић, Александра Ковачевић, Викторија Симић Драгојевић
}

Центар за клиничку фармакологију, Медицински факултет

Војномедицинске академије, Универзитет одбране у Београду

\title{
IMPORTANCE OF PHARMACOGENETICS FOR THERAPEUTIC USE OF CLOPIDOGREL
}

\author{
Nemanja Rančić ${ }^{1}$, Aleksandra Kovačević ${ }^{1}$, Viktorija Simić Dragojević ${ }^{1}$ \\ ${ }^{1}$ Centre for Clinical Pharmacology, Medical Faculty Military Medical Academy, \\ University of Defense, Belgrade
}

\section{СКРАЋЕНИЩЕ}

$\boldsymbol{A D P}$ - аденозин-дифосфат

P2Y12 - пуринергички рецептор на тромбоцитној мембрани

CУP- цитохром Р450

PCI- перкутана коронарна интервенција

$\boldsymbol{R P A}$ - Residual platelet activity

LTA - Light transmittance aggregometry

VASP - Vasodilatator-stimulated phosphoprotein

\section{САЖЕТАК}

Цереброваскуларна и кардиоваскуларна обољења су један од водећих узрока смрти широм света. Самим тим, њихова терапија има велики значај. Важно место у терапији заузима клопидогрел, самостално или у комбинацији са аспирином. Проблем који се јавља у лечењу јесте слабији одговор на стандардну терапију, а тиме и повећана стопа поновних кардиоваскуларних догађаја. Овај слабији одговор на терапију клопидогрелом последица је пре свега фармакогеномске модификације ензима цитохрома P450, као и Пгликопротеина одговорних за апсорпцију и биорасположивост. Код пацијената који показују слабији одговор на стандардну антиагрегациону терапију препоручује се генетско тестирање.

Кључне речи: клопидогрел, резистенција, тромбоцити, интеракције лекова

\section{ABSTRACT}

Cerebrovascular and cardiovascular diseases are the worldwide leading causes of mortality. Therefore, therapy of these diseases is of great importance. Antiplatelet therapy with clopidogrel alone and in combination with aspirin has a prominent place. The major problem in clopidogrel therapy is patients poor response to standard protocols of treatment, followed by increased rate of repeated cardiovascular events. Main cause of the poor response to antiplatelet clopidogrel therapy is pharmacogenomic modification of cytochrome P450 as well as P-glycoprotein, responsible for absorption and bioavailability. Genetic testing is recommended for patients who respond poorly to standard antiplatelet therapy.

Key words: clopidogrel, resistance, platelets, drug-drug interactions 


\section{УВОД}

Цереброваскуларна и кардиоваскуларна обољења су један од водећих узрока смрти широм света, због чега терапија ових обољења има велики значај ${ }^{1}$. Антитромбоцитни лекови, посебно инхибитори агрегације тромбоцита која је посредована аденозин-дифосфатом (ADP) (тиклопидин, клопидогрел, прасугрел), заузимају значајно место у њиховој терапији ${ }^{2}$. Посебан проблем који се јавља у лечењу ових стања јесте слабији одговор пацијената на стандардну терапију, а самим тим и повећана стопа поновних кардиоваскуларних догађаја.

Клопидогрел, антитромбоцитни лек из групе тиенопиридина, смањује ризик од коронарног догађаја за $8,7 \%$ више од аспирина, a још веће снижење се постиже двојном терапијом аспирина и клопидогрела због њиховог синергистичког ефекта, па се ово сматра стандардном терапијом акутног коронарног синдрома ${ }^{3,4}$.

Клопидогрел има антагонистичко дејство на нивоу пуринергичког рецептора на тромбоцитној мембрани (Р2Y12 рецептор), за који се као агонист везује ADP, који је веома битан у активацији тромбоцита у процесу агрегације ${ }^{2,4,5}$. Блокада ADP рецептора је селективна и иреверзибилна (10-11 дана $)^{2,5-7}$.

\section{ФАРМАКОКИНЕТИКА}

Клопидогрел се уноси оралним путем у неактивном облику. Добро се апсорбује (око $50 \%$ примењене дозе), пре свега у дуоденуму, (чему се опире П-гликопротеин) и доспева у јетру, где се метаболише ${ }^{3}$. Ова реакција је двостепена и посредована је изоформама ензима цитохрома $P 450(\text { CYP) (слика } 1)^{3}$. Најпре се $90 \%$ клопидогрел-бисулфата (пролек) у првој етапи дејством јетрине естеразе претвори у неактиван метаболит, а само $10 \%$ бива метаболисано преко неколико изоформи ензима цитохрома $P 450$ у интермедијарни 2-оксоклопидогрел. Овај интермедијарни продукт се даље метаболише такође помоћу изоформи ензима цитохрома $P 450$ у активни метаболит - R130964 (око 5\%), а преосталих 5\% се метаболише јетрином естеразом у неактиван метаболит ${ }^{3,6,8,9}$. Естераза катализује метаболички пут насупрот $C Y P$ ензимима и било који фактор који успорава метаболизам преко СYP ензима фаворизује трансформацију преко јетрине естеразе, а последично се мање лека преводи у активни метаболит. На тај начин, од целокупног орално унесеног лека, само 5$15 \%$ се преведе у активни метаболит ${ }^{3,10,11}$. Време полуелиминације лека је 7-8 сати. Елиминација метаболита се одвија путем урина $(50 \%)$ и столицом (46\%). Код оштећења бубрега и јетре, иако неки аутори сугеришу да то није потребно, треба водити рачуна о висини прописане дозе клопидогрела и вршити њено прилагођавање ${ }^{12}$. На биорасположивост клопидогрела не утичу храна и антациди ${ }^{13}$.

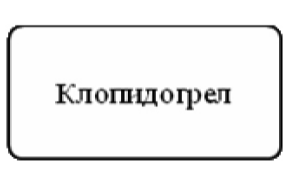

CYP2C19

CYP1A2

CYP2B6

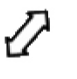

1 јетрина
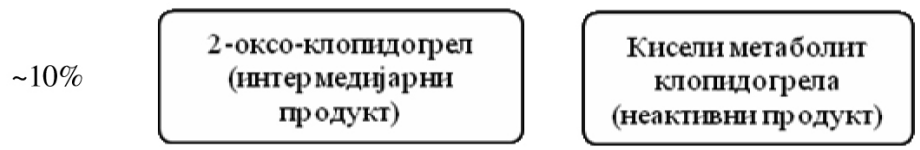

$\sim 90 \%$ роду

(неактивн пр одукт)

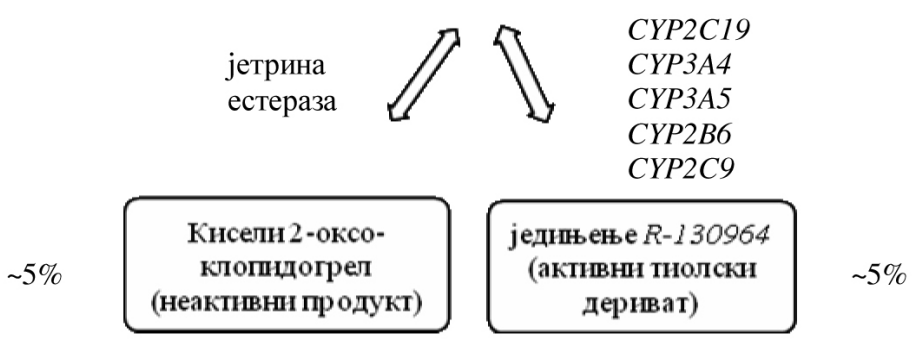

Слика 1. Метаболизам клопидогрела у јетри 


\section{ФАРМАКОДИНАМИКА}

Клопидогрел је 40 пута активнији инхибитор агрегације тромбоцита од тиклопидина, при чему показује дозно-зависни ефекат ${ }^{14}$. Зато се препоручује започињање лечења са ударном дозом од 300 или $600 \mathrm{mg}$ (посебно битно код пацијената којима је уграђен стент, где ова ударна доза скраћује време до максималне инхибиције од $80 \%$ на само 5 сати), а онда наставити са дозом одржавања од 75 или $150 \mathrm{mg}$ на дан у једној дневној дози ${ }^{2,15-17}$. У случају почетног дозирања од $75 \mathrm{mg}$ на дан, до постизања максималног одговора потребно је 3 до 7 дана $^{6}$. Ова терапија би требало да траје 4 недеље до 12 месеци, а неки аутори препоручују и дуже (код уграђеног стента обложеног леком примењује се и дуже од 15 месеци); при томе, треба водити рачуна да продужење терапије преко 12 месеци повећава ризик од крварења ${ }^{18}$. Пет дана по престанку узимања лека, време крварења и агрегација тромбоцита враћају се у оквир нормалних вредности ${ }^{2,4}$.

\section{КЛИНИЧКА ПРИМЕНА}

Клопидогрел се примењује као стандардна терапија у секундарној превенцији исхемијских догађаја (акутни инфаркт миокарда, исхемијски мождани удар, тромбоемболизам и смрт због кардиоваскуларних поремећаја) и превенцији поновне оклузије после имплантације стента ${ }^{2,7,19-22}$. Лек се најчешће примењује заједно са аспирином или засебно, код пацијената преосетљивих на аспирин или када постоје веома изражене гастроинтестиналне тегобе после примене аспирина ${ }^{3,4,18}$.

Терапија клопидогрелом се примењује у следећим стањима ${ }^{2,4}$ :

- нестабилна ангина пекторис и non- $Q$ инфаркт;

- инфаркт миокарда са $S T$ елевацијом, без обзира на то да ли је уграђен стент;

- болест периферних артерија (хронична периферна оклузивна артеријска болест), коронарна и цереброваскуларна болест - препоручује се аспирин, осим код алергије и неподношљивости аспирина, кад је главна алтернатива клопидогрел (код асимптоматске каротидне стенозе препоручује се дуготрајна терапија аспирином);

- аортокоронарни by-pass;
- превенција тромбозе стента (заједно са аспирином);

- превенција можданог удара;

- пацијенти са PCI (перкутаном коронарном интервенцијом);

- иницијална терапија клопидогрелом (заједно са аспирином) код транзиторног исхемичног атака и можданог удара који не настаје на бази емболије срчаног порекла (атеротромботични, криптогени и лакунарни мождани удар);

- код деце са поновљеним артеријским исхемичним можданим ударом и транзиторним исхемичним атацима, аспирин треба заменити клопидогрелом или оралним антикоагулансом (варфарин или нискомолекулски хепарин $)^{4}$.

\section{"РЕЗИСТЕНЦИЈА НА КЛОПИДОГРЕЛ"}

"Резистенција на клопидогрел" је делимичан или потпуни изостанак инхибиције агрегације тромбоцита на терапију клопидогрелом и запажена је код 4-30\% пацијената $2,23-$ 27 . Ризик од коронарног догађаја код ових пацијената је значајно већи. Сматра се да се ради о веома израженој промењивости у одговору на лек, у којој учествује генетски полиморфизам, ћелијска варијабилност (експресија рецептора за клопидогрел, промет тромбоцита) и клиничко стање пацијента (старост, пол, дијабетес, хронична бубрежна обољења ${ }^{28,29}$. Око 5 до 30\% пацијената (сваки трећи пацијент) због интериндивидуалне варијабилности не одговара на почетну терапију клопидогрелом ${ }^{30-32}$.

Фармакогеномске модификације ензима који метаболишу овај лек сматрају се најодговорнијим за ову резистенцију. Најважнији ензим у метаболизму клопидогрела је СУР2C19, јер учествује у оба степена биотрансформације лека до активног метаболи$\mathrm{Ta}^{33,34}$. Овај ензим има више од 14 алелских форми $(* 1 \mathrm{~A}, * 1 \mathrm{~B}, * 2, * 3, * 4, * 5 \mathrm{~A}, * 6, * 7, * 8$, $* 9, * 10, * 12, * 13, * 14, * 17)$, али су најбитније $* 1$ и $* 2$ изоформа ${ }^{21,34}$. Ензими $* 1$ изоформе нормално метаболишу лек, док ензими $* 2, * 3$, *4 и *5 изоформе споро метаболишу лек, па код пацијената са таквим изоформама после узимања клопидогрела у уобичајеним дозама нема очекиваног терапијског дејства лека (јер за дејство лека неопходно је да се лек преведе у активну форму метаболизмом преко цитохрома $P 450)^{22,35,36}$. CYP2C19*2/2 алелна варијанта показала је јаку корелацију са слабијим 
одговором на клопидогрел, посебно код пацијената млађих од 45 година код којих се сматра главним узроком лошег одговора на терапију ${ }^{14,34,37}$. Изоформа ензима $* 2$ је заступљена у различитом проценту у хуманој популацији, у зависности од етничке припадности: 20-30\% код белаца, 35-45\% код афроамериканаца и 50-65\% код азијата, док је учесталост свих осталих изоформи око $1 \%{ }^{21,38,39}$. Пацијенти са изоформом СYP2C19*17 брзо метаболишу лек ${ }^{21}$. Геномским испитивањима је показана измењена фармакокинетика клопидогрела код пацијената који споро метаболишу лек, што доводи до ниже концентрације његових активних метаболита у крви, а самим тим и слабијег антитромбоцитног дејства ${ }^{21}$. Пацијенти резистентни на клопидогрел имају троструко до четвороструко већи ризик од кардиоваскуларног напада са или без смртног исхода ${ }^{25}$. Процењено је да су 2-15\% белаца, $4 \%$ црнаца и $10-25 \%$ југоисточних азијата спори метаболизери $^{40}$.

ABCB1 (MDR1) ген који кодира П-гликопротеин, може такође бити узрок резистенције, јер генска модификација ове ефлукс пумпе може значајно утицати на апсорпцију клопидогрела и смањити његову биорасположивост, а самим тим и одговор на иницијалну терапију. Такође се сматра да интеракција лекова на нивоу П-гликопротеина може имати значајну улогу у смањеном одговору на клопидогрел ${ }^{16,41}$.

Пацијенти који су оболели од дијабетес мелитуса имају слабији одговор на клопидогрел $^{42}$.

\section{МЕРЕЊЕ ДЕЈСТВА КЛОПИДОГРЕЛА}

Дејство клопидогрела се процењује мерењем активности преосталих тромбоцита (Residual platelet activity- RPA), која је повећана код пацијената који споро метаболишу лек (за око 9\% у односу на оне који нормално метаболишу лек) и удружена је са повећаним ризиком од поновног нежељеног кардиоваскуларног догађаја $\mathrm{a}^{21,37,43,44}$. Постоји већи број тестова, али је златни стандард Light transmittance aggregometry (LTA), а остале методе су Flow cytometry VASP assay, Verify Now $P 2 Y_{12}$ Assay, Multiple electrode aggregometry и друге ${ }^{14,21,45-47}$. Повремено је потребно пратити знаке крварења, хемоглобин и хематокрит. Најбољи показатељ слабијег терапијског одговора је инхибиција тромбоцита мања од $2 \%$ после 2 сата од дате терапије ${ }^{22}$. Клопи- догрел иреверзибилно инхибира везивање $A D P$ за $P 2 Y_{12}$ рецептор и спречава фосфорилацију фосфопротеина који је стимулисан вазодилататором (Vasodilatator-stimulated phosphoprotein - VASP), па због тога повишене вредности VASP могу бити добар показатељ резистенције на клопидогрел ${ }^{48}$.

\section{ИНТЕРАКЦИЈЕ КЛОПИДОГРЕЛА}

У табели 1 приказене су најзначајније интеракције клопидогрела са другим лековима.

Иако се доскора сматрало да истовремена примена клопидогрела и статина доводи до појаве резистенције на клопидогрел ${ }^{49-51}$, данас ова претпоставка није потврђена ${ }^{52}$. При узимању клопидогрела може се користити и лек из групе статина, без одабира о којој фармаколошкој подгрупи статина се ради, тј. независно од тога да ли се лек метаболише (аторвастатин, ловастатин, симвастатин, церивастатин) или не (правастатин, флувастатин) преко СYP $3 A 4^{14,18,52}$.

Треба бити опрезан при истовременој примени клопидогрела и нестероидних антиинфламаторних лекова, јер клопидогрел инхибира њихов метаболизам преко СYР 2 C9 ензима. Као последица ове интеракције може доћи до значајног скока концентрација нестероидних антиимфламаторних лекова у крви и последичног повећања ризика од крварења ${ }^{4}$.

Комбинацијом клопидогрела са антикоагулансима и другим антитромбоцитним лековима повећава се ризик од крварења ${ }^{4}$.

Кетоконазол смањује ниво активног метаболита клопидогрела у плазми инхибицијом $C Y P 3 A 4 / 5$, па је и одговор слабији ${ }^{53}$.

Клопидогрел смањује конверзију бупропиона у његов активни метаболит, инхибицијом СУР2В6 ензима ${ }^{54}$.

Интеракције инхибитора протонске пумпе са клопидогрелом могуће су посредством инхибиције CYP2C19 ензима, али и променом $\mathrm{pH}$ желуца од стране инхибитора протонске пумпе, чиме се омета апсорпција клопидогрела $^{55,56}$. Код пацијената на терапији клопидогрелом и инхибиторима протонске пумпе већа је стопа срчаног напада у поређењу са онима који су само на терапији клопидогрелом $^{4,14,57}$. Клинички значај комбинације је контрадикторан и зато се ова комбинација лекова мора разматрати индивидуално, ${ }^{4,11}$. Преко СРР2C19 се метаболише омепразол, док се езомепразол, пантопразол и лансопразол метаболишу у мањој мери преко овог 
ензима. Рабепразол се не метаболише овим ензимским системом, али се метаболише његов метаболит, па је и могућност интеракција са рабепразолом најмања ${ }^{56}$. Код пацијената који су били на терапији клопидогрелом и инхибиторима протонске пумпе, после укидања инхибитора протонске пумпе повећава се ризик од крварења у дигестивном тракту ${ }^{3}$.
Због свега овога, данас постоји јасна препорука да код пацијената који су на дуготрајној терапији клопидогрелом и аспирином треба размислити о увођењу инхибитора протонске пумпе само у строгим индикацијама, како би се смањио ризик од крварења у дигестивном тракту ${ }^{3}$.

Табела 1. Интеракције клопидогрела са другим лековима

\begin{tabular}{|c|c|c|}
\hline Лек & $\begin{array}{l}\text { Интеракција са клопидо- } \\
\text { грелом }\end{array}$ & Механизам интеракције \\
\hline Блокатори калцијумских канала & Доказана & CYP $3 A 4 / 5$ \\
\hline Нестероидни антиинфламаторни лекови & Доказана & CYP2C9 \\
\hline Антикоагуланси & Доказана & CYP2C9 \\
\hline Други антитромбоцитни лекови (тиклопидин) & Доказана & - \\
\hline Кетоконазол & Доказана & CYP3A4/5 \\
\hline Бупропион & Доказана & CYP2B6 \\
\hline Циклоспорин & Доказана & CYP3A4 \\
\hline Инхибитори протонске пумпе & Доказана & CYP2C19 \\
\hline Гемфиброзил & Доказана & - \\
\hline Кетоконазол & Доказана & CYP $3 A 4 / 5$ \\
\hline Миконазол & Доказана & CYP2C9 \\
\hline Сертралин & Доказана & СYP3A4 \\
\hline Амјодарон & Могућа & CYP $3 A 4$ \\
\hline Кларитромицин & Могућа & CYP $3 A 4 / 5$ \\
\hline Фенитоин, тамоксифен, толбутамид & Потребно праћење терапије & CYP2C9 \\
\hline Глукозамини & Потребно праћење терапије & CYP2C9 \\
\hline Макролидни антибиотици & Потребно праћење терапије & CYP2C9 \\
\hline Омега-3-масне киселине & Потребно праћење терапије & CYP2C9 \\
\hline Пентоксифилин & Потребно праћење терапије & CYP2C9 \\
\hline Аналози простациклина & Потребно праћење терапије & CYP2C9 \\
\hline Рифампицин и деривати & Потребно праћење терапије & CYP2C9 \\
\hline Циталопрам, & Потребно праћење терапије & CYP2C19 \\
\hline Еноксапарин & Потребно праћење терапије & - \\
\hline Статини & Није доказана & - \\
\hline
\end{tabular}

Табела 2. Препоруке за дозирање клопидогрела према индикацијама

\begin{tabular}{|l|l|}
\hline Индикација & Препоручена терапија клопидогрелом \\
\hline $\begin{array}{l}\text { Акутни коронарни синдром (акутни инфаркт мио- } \\
\text { карда без } S T \text { елевације, нестабилна ангина) }\end{array}$ & $\begin{array}{l}\text { Ударна доза клопидогрела 300-600 mg, одржавање } \\
\text { са 75 mg дневно комбиновано са аспирином (75-325 } \\
\text { mg иницијално, а наставити са 75-162 mg на дан) } \\
\text { или чак 150 mg доза одржавања током 6 дана а онда } \\
\text { прећи на 75 mg }\end{array}$ \\
\hline $\begin{array}{l}\text { Акутни коронарни синдром (акутни инфаркт мио- } \\
\text { карда са } S T \text { елевацијом) }\end{array}$ & $\begin{array}{l}\text { Почети ударном дозом од 300 mg а наставити са 75 } \\
\text { mg заједно са аспирином (162-325 mg), са или без } \\
\text { тромболизе }\end{array}$ \\
\hline $\begin{array}{l}\text { Уграђен коронарни стент- PCI } \\
\text { Стентови обложени леком (drug-eluting stents) } \\
\text { Стентови необложени леком (bare-metal stents) }\end{array}$ & $\begin{array}{l}\text { Ударна доза } 300 \mathrm{mg} 1 \text { дан или 6 сати пре уградње } \\
\text { стента или 600 mg 2 сата пре уградње стента, } \\
\text { одржавање са 75 mg дневно комбиновано са аспи- } \\
\text { рином (75-325 mg иницијално, а наставити са 75-162 } \\
\text { mg на дан) }\end{array}$ \\
\hline $\begin{array}{l}\text { Мождани удар, болести периферних артерија, про- } \\
\text { филакса тромбоемболијских компликација }\end{array}$ & $\begin{array}{l}75 \mathrm{mg} \text { клопидогрела на дан заједно са аспирином } \\
\text { (162-325 mg) после ударне дозе од 300 mg }\end{array}$ \\
\hline $\begin{array}{l}\text { Пацијенати код којих је постављена индикација за } \\
\text { терапију антикоагулантним лековима (атријална } \\
\text { фибрилација, дисфункција леве коморе, церебрална } \\
\text { емболија, механичка срчана валвула, обимна } \\
\text { абнормалност срчаног мишића) }\end{array}$ & $\begin{array}{l}\text { Заједно аспирин, антикоагуланси и клопидогрел у } \\
\text { дози од 75 mg }\end{array}$ \\
\hline
\end{tabular}


Блокатори калцијумских канала су СУРЗА4 инхибитори, и ако се узимају са клопидогрелом, изгледа да ступају у интеракциjy, јер је код ових пацијената RPA повећан, а стопа поновних догађаја такође повећана (25\% наспрам $8 \%$ у групи код које нису примењени калцијумски блокатори $)^{14}$.

\section{ПРЕПОРУКЕ ЗА ПРИМЕНУ КЛОПИДОГРЕЛА}

У табели 2 приказане су препоруке за дозирање клопидогрела у одређеним индикацијама $^{2,4,18,58}$. Клопидогрел се најчешће примењује у комбинацији са аспирином, јер је показано да је нижа стопа поновног срчаног напада и тромбоза стента код ове двоструке терапије ${ }^{4,18}$.

Код пацијената који нису животно угрожени (акутни коронарни синдром без $S T$ елевације и нестабилна ангина) препоручује се генотипизација (одређивање генотипа) пре отпочињања терапије клопидогрелом. Код акутног коронарног синдрома са $S T$ елевацијом за то нема нема времена, јер процедура траје 6-12 сати, већ се одмах почиње са ургентном тромболитичком и антиагрегационом терапијом, а одређивање генотипа се може радити касније ${ }^{4}$.

Битно је водити рачуна и о дози клопидогрела. Стандардним свакодневним давањем дозе од $75 \mathrm{mg}$ постиже се инхибиција тромбоцитне агрегације индуковане $A D P$ за око $50 \%{ }^{14}$. Међутим, ударном дозом од $300 \mathrm{mg}$ већ се унутар 4 сата постиже 38-40\% инхибиције, а ударном доза од $600 \mathrm{mg} 55-59 \%{ }^{14}$. Ако та доза износи $900 \mathrm{mg}$ даље се не повећава ниво активног принципа у плазми, па нема рационалног оправдања за њену примену (мада неки аутори нису сагласни са овом тврдњом) $)^{16,59}$. Ови подаци су потврда да се код клопидогрела ради о временски и дозно зависном ефекту. Код пацијената који споро метаболишу клопидогрел $($ CYP2C19*2/2 и $C Y P 2 C 19 * 3 / 3)$ показано је да ударна доза од $600 \mathrm{mg}$ и доза одржавања од $150 \mathrm{mg}$ повећавају антиагрегациони одговор 4 .

Клопидогрел са или без аспирина (са или без тромболитичке терапије) код акутног инфаркта миокарда без $S T$ елевације и нестабилне ангине требало би применити у трајању од месец до годину дана ${ }^{4}$. Код акутног инфаркта миокарда са $S T$ елевацијом терапија би требала да траје 14-28 дана, до максимално годину дана ${ }^{4}$. Ако је урађен $P C I$, код пације- ната са стентом који није обложен леком терапију би требало одржавати у континуитету 6 недеља, а код стента обложеног леком најмање годину дана ${ }^{4}$. Код мањих хирушких захвата (нпр. стоматолошке услуге) не сме се прекидати терапија, а ако се очекује велико крварење онда треба одложити интервенцију до завршетка антитромбоцитне терапије. Велике хирушке захвате одложити до завршетка терапије, а ако се мора урадити операција, онда се терапија клопидогрелом привремено прекида. Код пацијената са стентом, када треба да се ради хируршка интервенција, потребно је 5 дана пре саме интервенције обуставити клопидогрел, али давати аспирин, а онда након завршетка операције наставити са двојном терапијом ${ }^{4,18}$. Због утврђене варијабилности у одговору пацијената на клопидогрел, постоје препоруке за увођење у терапију новијих тиенопиридина, првенствено прасугрела, који би довео до брже инхибиције агрегације тромбоцита ${ }^{60}$. Међутим, применом прасугрела примећене су значајније нежељене реакције на лек, првенствено у виду повећаног ризика за крварење и настанак фаталних хеморагија ${ }^{61}$, што у комбинацији са већом ценом овог лека чини дискутабилном његову рутинску примену у пракси. Такође, клопидогрел је индикован и код стања у којима је прасугрел контраиндикован: прележани мождани удар или транзиторни исхемијски атак, тешка оштећења јетре, активна крварења и алергија на састојке препарата ${ }^{2}$.

Примена клопидогрела је контраиндикована код акутних крварења и стања код којих постоји опасност од крварења (недавне повреде и операције), интракранијалних крварења, пептичког улкуса, улцерација у дигестивном тракту итд. ${ }^{2,4}$. Спектар нежељених реакција клопидогрела је сличан аспирину, али клопидогрел мање надражује желудац па су ређи диспепсија, болови, гастритис и улкуси, али су дијареја и алергијске реакције (серумска болест, ангиоедем) чешће $\mathrm{e}^{3,4}$.

\section{ЗАКЉУЧАК}

Примена клопидогрела код већине клиничких ситуација у којима се примењује захтева сагледавање односа трошкова и ефеката, како би се донела адекватна одлука о његовој примени у комбинацији са аспирином. Рутинско одређивање резидуалне тромбоцитне активности код свих пацијената на терапији аспирином и/или клопидогрелом се не препоручује, већ само код оних особа које показују 
слабији одговор на стандардну антиагрегациону терапију ${ }^{18}$. Утврђивање резистенције на клопидогрел захтева генетско тестирање применом тестова за идентификацију врсте СYР2C19 генотипа у циљу индивидуализације терапије клопидогрелом ${ }^{4}$. Међутим, рутинско генетско испитивање код свих пацијената на терапији клопидогрелом се не може применити из финансијских разлога, као и због непостојања јасних препорука за избор пацијената који ће бити на овај начин тестирани, па је њихов одабир још увек индивидуалан $^{4,14,62}$.

\section{ЗАХВАЛНИЦА}

Аутори би овом приликом желели да се захвале Министарству науке и просвете Републике Србије за пружену финансијску помоћ у реализацији примарне студије, која је пружила основу за писање овог чланка, а у оквиру пројекта број 175014.

\section{ЛИТЕРАТУРА}

1. Ilić S. Akutni koronarni sindrom. U: Ilić S, Lović B, Marković V, urednici. Interna medicina, Knjiga II. Niš: Prosveta, 2004: 48-54.

2. Kažić $\mathrm{T}$, Ostojić $\mathrm{M}$, urednici. Klinička kardiovaskularna farmakologija. Beograd: Integra, 2009.

3. Anderson CD, Biffi A, Greenberg SM, Rosand J. Personalized approaches to clopidogrel therapy: are we there yet? Stroke 2010; 41(12): 2997-3002.

4. American Society of Health-system Pharmacists. AHFS Drug information. Bethesada: Maryland, 2011.

5. Gachet C. ADP receptors of platelets and their inhibition. Thromb Haemost 2001; 86(1): 22-32.

6. Di Girolamo G, Czerniuk P, Bertuola R, Keller GA. Bioequivalence of two tablet formulations of clopidogrel in healthy Argentinian volunteers: a single-dose, randomized-sequence, open-label crossover study. Clin Ther 2010; 32(1): 161-70.

7. Savi P, Herbert JM. Clopidogrel and ticlopidine: P2Y12 adenosine diphosphate-receptor antagonists for the prevention of atherothrombosis. Semin Thromb Hemost 2005; 31(2): 174-83.

8. Hulot JS, Bura A, Villard E, et al. Cytochrome P450 2C19 loss-of-function polymorphism is a major determinant of clopidogrel responsiveness in healthy subjects. Blood 2006; 108(7): 2244-7.

9. Kazui M, Nishiya Y, Ishizuka T, et al. Identification of the human cytochrome P450 enzymes involved in the two oxidative steps in the bioactivation of clopidogrel to its pharmacologically active metabolite. Drug Metab Dispos 2010; 38(1): 92-9.

10. Farid NA, Kurihara A, Wrighton SA. Metabolism and disposition of the thienopyridine antiplatelet drugs ticlopidine, clopidogrel, and prasugrel in humans. J Clin Pharmacol 2010; 50(2): 126-42.
11. Giorgi MA, Di Girolamo G, González CD. Nonresponders to clopidogrel: pharmacokinetics and interactions involved. Expert Opin Pharmacother 2010; 11(14): 2391-403.

12. Slugg PH, Much DR, Smith WB, Vargas R, Nichola $P$, Necciari J. Cirrhosis does not affect the pharmacokinetics and pharmacodynamics of clopidogrel. J Clin Pharmacol 2000; 40(4): 396-401.

13. McEwen J, Strauch G, Perles P, et al. Clopidogrel bioavailability: Absence of influence of food or antacids. Semin Thromb Hemost 1999; 25 Suppl 2: 47-50.

14. Ma TK, Lam YY, Tan VP, Kiernan TJ, Yan BP. Impact of genetic and acquired alteration in cytochrome P450 system on pharmacologic and clinical response to clopidogrel. Pharmacol Ther 2010; 125(2): 249-59.

15. Taubert D, Kastrati A, Harlfinger S, et al. Pharmacokinetics of clopidogrel after administration of a high loading dose. Thromb Haemost 2004; 92(2): 311-6.

16. von Beckerath N, Taubert D, Pogatsa-Murray G, Schömig E, Kastrati A, Schömig A. Absorption, metabolization, and antiplatelet effects of 300-, 600-, and 900-mg loading doses of clopidogrel: Results of the ISAR-CHOICE (Intracoronary Stenting and Antithrombotic Regimen: Chosen between 3 high oral doses for immediate Clopidogrel effect) Trial. Circulation 2005; 112(19): 2946-50.

17. Mullangi R, Srinivas NR. Clopidogrel: Review of bioanalytical methods, pharmacokinetics/pharmacodynamics, and update on recent trends in drug-drug interaction studies. Biomed Chromatogr 2009; 23(1): 26-41.

18. Second Chinese Cardiac Study Collaborative group. A randomized trial of clopidogrel plus aspirin, and of metoprolol, among patients with suspected acute myocardial infarction. J Cardiovasc risk 2000; 7(6): 435-41.

19. Diener HC, Ringleb PA, Savi P. Clopidogrel for the secondary prevention of stroke. Expert Opin Pharmacother 2005; 6(5): 755-64.

20. Fox KA, Chelliah R. Clopidogrel: An updated and comprehensive review. Expert Opin Drug Metab Toxicol 2007; 3(4): 621-31.

21. Varenhorst C, James S, Erlinge D, et al. Genetic variation of CYP2C19 affects both pharmacokinetic and pharmacodynamic responses to clopidogrel but not prasugrel in aspirin-treated patients with coronary artery disease. Eur Heart J 2009; 30(14): 1744-52.

22. Gladding $\mathrm{P}$, Webster $\mathrm{M}$, Zeng $\mathrm{I}$, et al. The pharmacogenetics and pharmacodynamics of clopidogrel response: an analysis from the PRINC (Plavix Response in Coronary Intervention) trial. JACC Cardiovasc Interv 2008; 1(6): 620-7.

23. Nguyen TA, Diodati JG, Pharand C. Resistance to clopidogrel: A review of the evidence. J Am Coll Cardiol 2005; 45(8): 1157-64.

24. Sofi F, Marcucci R, Gori AM, Giusti B, Abbate $\mathrm{R}$, Gensini GF. Clopidogrel non-responsiveness and risk of cardiovascular morbidity. Thromb Haemost 2010; 103(4): 841-8.

25. Combescure C, Fontana P, Mallouk N, et al. Clinical implications of clopidogrel non-response in 
cardiovascular patients: a systematic review and metaanalysis. J Thromb Haemost 2010; 8(5): 923-33.

26. Djukanovic N, Todorovic Z, Grdinic A, Prostran M, Ostojic $\mathrm{M}$. Thienopyridine resistance among patients undergoing intracoronary stent implantation and treated with dual antiplatelet therapy: assessment of some modifying factors. J Pharmacol Sci 2008; 107(4): 451-5.

27. Wang TH, Bhatt DL, Topol EJ. Aspirin and clopidogrel resistance: an emerging clinical entity. Eur Heart J 2006; 27(6): 647-54.

28. Ernesto O, Martin H, Ronald D. Clopidogrel resistance. Heart Lung Circ 2007; 16(3): S17-28.

29. Angiolillo DJ, Fernandez-Ortiz A, Bernardo E, et al. Variability in individual responsiveness to clopidogrel: clinical implications, management, and future perspectives. J Am Coll Cardiol 2007; 49(14): 1505-16.

30. Serebruany VL, Steinhubl SR, Berger PB, Malinin AI, Bhatt DL, Topol EJ. Variability in platelet responsiveness to clopidogrel among 544 individuals. J Am Coll Cardiol 2005; 45(2): 246-51.

31. Gurbel PA, Bliden KP, Hiatt BL, O'Connor CM. Clopidogrel for coronary stenting: response variability, drug resistance, and the effect of pretreatment platelet reactivity. Circulation 2003; 107(23): 2908-13.

32. Muller I, Besta F, Schulz C, Massberg S, Schonig A, Gawaz M. Prevalence of clopidogrel non-responders among patients with stable angina pectoris scheduled for elective coronary stent placement. Thromb Haemost 2003; 89(5): 783-7.

33. Brandt JT, Close SL, Iturria SJ, et al. Common polymorphisms of CYP2C19 and CYP2C9 affect the pharmacokinetic and pharmacodynamic response to clopidogrel but not prasugrel. J Thromb Haemost 2007: 5(12): 2429-36.

34. Collet JP, Hulot JS, Pena A, et al. Cytochrome P450 2C19 polymorphism in young patients treated with clopidogrel after myocardial infarction: a cohort study. Lancet 2009; 373(9660): 309-17.

35. Suh JW, Koo BK, Zhang SY, et al. Increased risk of atherothrombotic events associated with cytochrome P450 3A5 polymorphism in patients taking clopidogrel. CMAJ 2006; 174(12): 1715-22.

36. Fontana P, Hulot JS, De Moerloose P, Gaussem P. Influence of CYP2C19 and CYP3A4 gene polymorphisms on clopidogrel responsiveness in healthy subjects. J Thromb Haemost 2007; 5(10): 2153-5.

37. Shuldiner AR, O'Connell JR, Bliden KP, et al. Association of cytochrome P450 2C19 genotype with the antiplatelet effect and clinical efficacy of clopidogrel therapy. JAMA 2009; 302(8): 849-57.

38. Desta Z, Zhao X, Shin JG, Flockhart DA. Clinical significance of the cytochrome P450 2C19 genetic polymorphism. Clin Pharmacokinet 2002; 41(12): 913-58.

39. Kim KA, Park PW, Hong SJ, Park JY. The effect of CYP2C19 polymorphism on the pharmacokinetics and pharmacodynamics of clopidogrel: a possible mechanism for clopidogrel resistance. Clin Pharmacol Ther 2008; 84(2): 236-42.
40. Xie HG, Kim RB, Wood AJ, Stein CM. Molecular basis of ethnic differences in drug disposition and response. Annu Rev Pharmacol Toxicol 2001; 41: 815-50.

41. Taubert D, von Beckerath N, Grimberg G, et al. Impact of P-glycoprotein on clopidogrel absorption. Clin Pharmacol Ther 2006; 80(5): 486-501.

42. Geisler T, Anders N, Paterok M, et al. Platelet response to clopidogrel is attenuated in diabetic patients undergoing coronary stent implantation. Diabetes Care 2007; 30(2): 372-4.

43. Hulot JS, Bura A, Villard E, et al. Cytochrome P450 2C19 loss-of-function morphism is a major determinant of clopidogrel responsiveness in healthy subjects. Blood 2006; 108(7): 2244-7.

44. Mega JL, Close SL, Wiviott SD, et al. Cytochrome p-450 polymorphisms and response to clopidogrel. N Engl J Med 2009; 360(4): 354-62.

45. Ellis KJ, Stouffer GA, McLeod HL, Lee CR. Clopidogrel pharmacogenomics and risk of inadequate platelet inhibition: US FDA recommendations. Pharmacogenomics 2009; 10(11): 1799-817.

46. Pinto Slottow TL, Bonello L, Gavini R, et al. Prevalence of aspirin and clopidogrel resistance among patients with and without drug-eluting stent thrombosis. Am J Cardiol 2009; 104(4): 525-30.

47. Djukanović N, Todorović Z, Njegomirović S, Ostojić M, Prostran M. Advantages and limitations of clopidogrel response testing methods. Vojnosanit Pregl 2012; 69(4): 353-7.

48. Stegnar M. Platelet function tests and resistance to antiplatelet therapy. Srp Arh Celok Lek 2010; 138(Suppl 1): 59-63.

49. Gurbel PA, Cummings CC, Bell CR, et al. Onset and extent of platelet inhibition by clopidogrel loading in patients undergoing elective coronary stenting: the Plavix Reduction of New Thrombus Occurrence (PRONTO) trial. Am Heart J 2003; 145(2): 239-47.

50. Serebruany VL, Midei MG, Malinin AI, et al. Absence of interaction between atorvastatin or other statins and clopidogrel: results from the interaction study. Arch Intern Med 2004; 164(18): 2051-7.

51. Vinholt P, Poulsen TS, Korsholm L, et al. The antiplatelet effect of clopidogrel is not attenuated by statin treatment in stable patients with ischemic heart disease. Thromb Haemost 2005; 94(2): 438-43.

52. Saw J, Brennan DM, Steinhubl SR, et al. Lack of evidence of a clopidogrel-statin interaction in the CHARISMA trial. J Am Coll Cardiol 2007; 50(4): 291-5.

53. Farid NA, Payne CD, Small DS, et al. Cytochrome P450 3A inhibition by ketoconazole affects prasugrel and clopidogrel pharmacokinetics and pharmacodynamics differently. Clin Pharmacol Ther 2007; 81(5): 735-41.

54. Turpeinen M, Tolonen A, Uusitalo J, Jalonen J, Pelkonen O, Laine K. Effect of clopidogrel and ticlopidine on cytochrome P450 2B6 activity as measured by bupropion hydroxylation. Clin Pharmacol Ther 2005; 77(6): 553-9.

55. Gilard M, Arnaud B, Cornily JC, et al. Influence of omeprazole on the antiplatelet action of clopidogrel associated with aspirin: the randomized, double- 
blind OCLA (Omeprazole CLopidogrel Aspirin) study. J Am Coll Cardiol 2008; 51(3): 256-60.

56. Bhatt DL, Scheiman J, Abraham NS, et al. ACCF/ACG/AHA 2008 expert consensus document on reducing the gastrointestinal risks of antiplatelet therapy and NSAID use: a report of the American College of Cardiology Foundation Task Force on Clinical Expert Consensus Documents. J Am Coll Cardiol 2008; 52(18): 1502-17.

57. Aubert RE, Epstein RS, Teagarden JR, et al. Proton pump inhibitors effect on clopidogrel effectiveness: the clopidogrel Medco outcomes study. Circulation 2008; 118: S_815.

58. Steinhubl SR, Berger PB, Brennan DM, Topol EJ; CREDO Investigators. Optimal timing for the initiation of pre-treatment with $300 \mathrm{mg}$ clopidogrel before percutaneous coronary intervention. J Am Coll Cardiol 2006; 47(5): 939-43.

59. von Beckerath $\mathrm{N}$, von Beckerath $\mathrm{O}$, Koch $\mathrm{W}$, Eichinger M, Schömig A, Kastrati A. P2Y12 gene
H2 haplotype is not associated with increased adenosine diphosphate-induced platelet aggregation after initiation of clopidogrel therapy with a high loading dose. Blood Coagul Fibrinolysis 2005; 16(3): 199-204.

60. Wiviott SD, Antman EM, Winters KJ, et al. Randomized comparison of prasugrel (CS-747, LY640315), a novel thienopyridine P2Y12 antagonist, with clopidogrel in percutaneous coronary intervention: results of the Joint Utilization of Medications to Block Platelets Optimally (JUMBO)-TIMI 26 trial. Circulation 2005; 111(25): 3366-73.

61. Unger E. Weighing Benefits and Risks - The FDA's Review of Prasugrel. N Engl J Med 2009; 361(10): 942-5.

62. Cannon CP. Clopidogrel: to test or not to test? That is the question--still. Clin Chem 2011; 57(5): 659-61. 